that may be), yet there is no reason why this central issue should not have been tackled long ago. And there remain, of course, outstanding the thorny questions of the scale and the manner in which public funds should be used to support research. In other words, there has been somo progress in the past three years and some of it is valuable, but there is a danger that the British Government and its committeos will interpret the term science policy too literally, and thus attempt to make too many decisions at the centre. What Lord Jackson has been saying may help to push things in the other direction.

\section{ONE STEP ON}

THE announcement in Goneva a week ago that tho Russian and United States Governments have boen able to put forward a draft treaty intended to limit the proliferation of nuclear weapons is a hopeful if small step forward. The Disarmament Committee has been in session at Geneva for so long now that its credibility is much in danger of erosion. If it now becomes the forum for a realistic debate on the extent to which an agreement on the proliferation of nuclear weapons can be successfully controlled by international inspoction or by some other moans, much will have been done to restore its reputation-and the hopes of those outside the conference that some progress on disarmament may eventually be possible.

That said, however, it is inevitable that the weeks ahead will not be comfortable for the delegations represented at Geneva. After several months of private talks, the United States and the Soviet Union have boen forced to admit failure in their attempts to win agreement behind the scenes for the incorporation of safeguards provisions in the treaty they havo tabled. It is no surprise that things have turned out that way (see Nalure, 214, 753; 1967). The United States has plainly failed to win the agreement of the member nations of Euratom that responsibility for inspection and control should be placed with the International Atomic Energy Authority at Vienna, and the Soviet Union is entirely justified in its insistence that it would be improper to delegate this task to Euratom itself.

But this, of course, is only skirmishing. The difficulties ahead are much more serious. The outstanding uncertainty is whether the nations which are not nuclear powers, and which have no intention of making nuclear weapons for themselves, will stomach a treaty which pormanently confirms the nuclear powers in their present grandeur and throws the rest of tho world open to international inspection designed to stifle imitative ambitions. The nuclear powers have hithor. to been unreasonably hopeful of what the smaller nations would be happy to accept. For all the cheerfulness which has accompanied the tabling of tho treaty at Geneva, it remains unlikely that the nuelear powers will be able to win agreement from the smaller nations without making substantial concessions on their own account. But there are technical as well as political problems still to bo resolved. How feasible will it be to design cast-iron inspection systems? How soon could a safeguards system operate? In any case, what value is there in a treaty for the non-proliferation of nuclear explosives which does not include China and France as signatorios ?

In the circumstances it would be entirely sensible, if the nations now negotiating at Geneva wore to go back almost to the beginning of the discussions about the non-proliferation treaty. To begin with, some years ago, people seemed entirely happy with the notion that a non-proliferation treaty should not include a rigid safoguards system, at least at the beginning. Only when bellicose noises from West Germany had made the Russians take fright, a year or so ago, did the issue of safeguards become a central issue and a stumbling block. But things have changed a great deal in the past twelve months. European nations have clearly become much less concorned about the advantages or othorwise of manufacturing nuclear explosives for themselves. So may it not be prudent, to think now of a non-proliferation treaty in which the attempt, to design a safeguards system is replaced by something less ponderous? This would be something well worth trying for. One possible line of compromise would be an international agreement that all nations would make an honest public declaration at regular intervals of all activities connected with the exploitation of nuclear materials. Nuclear powers, for example. would be required every so often to say how much uranium they had converted into a fissile form, and how much of this they had committed to the manufacture of explosives. By itself, this would do a lot to salve the injured pride of smaller nations. But there is good reason to expect that such a system, operated by the non-nuclear powers and the rest, would be a good assurance that the manufacture of nuclear explosives would not spread. After all, in tho climate of mutual curiosity that would be certain to follow the signing of a non-proliferation treaty, it is extremely improbable that a nation forced to make public declarations of its activities in potentially important fields would be able successfully to keep secret the clandestine manufacture of nuclear explosives. At the same time, there would be good cause to hope that a treaty drawn on comparatively flexible lines like those would serve much more effectively than the cumbersome instrument now being negotiated as a platform from which further forays into disarmament might be attempted. Certainly it would be a great misfortune if there were so much bickering about safoguards in the months ahead at Geneva that the members of the Disarmament Committee would be persuaded to give up once more the hope of signing a treaty to bring the production of nucloar explosives by the nuclear powors under some kind of control. In other words, compromising on a system less rigid than the safeguards now in prospect would be not merely an immediate benefit but an insurance for the future. Will the negotiators seize this opportunity? 